\title{
Modification of the method to determine dehydrogenase activity in soils spiked with 1-butyl-3-methylimidazolium tetrafluoroborate [BMIM][BF$]$
}

\author{
Bello D. ${ }^{a}$, Muiño F. ${ }^{a}$, García-Carballal S. ${ }^{a}$, Salgado J. ${ }^{b}$, Trasar-Cepeda C. ${ }^{a *}$ \\ ${ }^{a}$ Soil Biochemistry Department, IIAG-CSIC, Apartado 122, E-15780 Santiago de Compostela, Spain; ${ }^{b}$ \\ Applied Physics Department, USC, E-15782 Santiago de Compostela, Spain
}

*Corresponding author: ctrasar@iiag.csic.es

\begin{abstract}
The ionic liquids (ILS) are often denominated as "green fluids", because they are considered as innocuous due to their negligible volatility. Due to this apparent innocuousness, the ILs are attracted a great attention as an alternative to traditional organic solvents, highly contaminant. However, the problem of contamination is not limited to the atmosphere, since also aquatic and terrestrial environments can be affected. Therefore, and because the toxic effects of ILs on the environment are largely unknown, research studies are needed to deepen this aspect before to assign them the appellation of "green fluids". Nevertheless, and despite the increased number of studies on different aspects of ILs in the last few years, the toxicity of these compounds to the environment in general, and to the soils in particular, only rarely is investigated. One of the most used ILs in different applications is 1-butyl-3-methylimidazolium

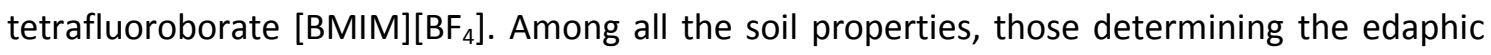
metabolism, and especially the enzymatic activities, are highly sensitive to ascertain the disturbance caused by any external agent. Given the lack of studies investigating the effect of ILS on the edaphic environment, before the use of enzymatic activities as indicators of the toxicity for soils of any given IL, it is necessary to test if classical methods to determine the soil enzymatic activities are adequate for their use in soils spiked with that given IL. In this study we investigated the suitability of dehydrogenase method to determine the activity of this

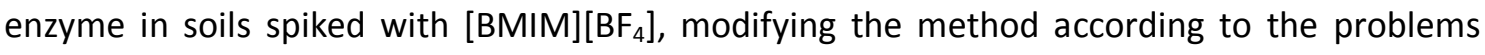
identified.
\end{abstract}

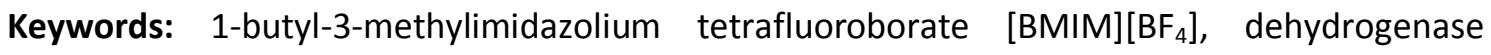
activity, soil contamination, soil enzymes.

\section{Introduction}

In the last few years there has been a growing interest in ionic liquids (ILS), so that there are an increasing number of studies related to diverse aspects of LIs, and therefore also the number 
of publications has exponentially increased. The interest on ILs is due to diverse facts. On the one hand, the ILs have some properties (negligible vapor pressure, high polarity, low inflammability, high ionic conductivity, etc.) that make them appropriate for multiple applications as, for example, as lubricants (Verdía et al., 2012; Salgado et al., 2013) or as thermic fluids (Pérez de los Ríos y Hernández, 2014). On the other hand, and due to their negligible volatility (Pérez de los Ríos y Hernández, 2014), ILs are considered as innocuous and thus they are often denominated as "green fluids". However, contamination is not limited to the atmosphere. The fact that IL are not volatile, not necessarily means that they are innocuous, as also aquatic and terrestrial environments must be taking into consideration, as they are also probable receptors of ILs from accidental spills. Nevertheless, the toxicity of these compounds to the environment in general, and to the soils in particular, only rarely is investigated. Therefore, and because the toxic effects of ILS on the environment are largely unknown, research studies are needed to deepen this aspect before to assign them the appellation of "green fluids". One of the most used ILs in different applications is 1-butyl-3-

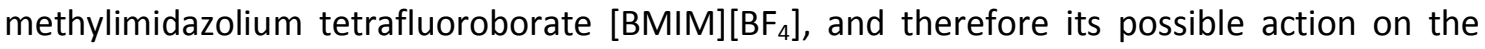
environment should be investigated before its use became too general.

Since the soil is a non-renewable resource, the preservation of its quality is fundamental for environmental conservation (Cihacek et al., 1996). Among all the soil properties, those determining the edaphic metabolism, and especially the enzymatic activities, are highly sensitive to ascertain the disturbance caused by any external agent (Nannipieri, 1994; Doran and Parkin, 1994; Dick, 1997). Dehydrogenase is only present in viable cells, and it only depends on the active edaphic microbiota (Skujins, 1973, 1978; Trevors, 1984), and for that reason may be considered as a direct measure of soil microbial activity (García and Hernández, 1997). Therefore, and although its behavior is very variable (Trasar-Cepeda et al., 2000), the dehydrogenase is one of the soil enzymes most widely used to investigate the effect of any disturbing agent, though. However, and given the lack of studies investigating the effect of ILs on the edaphic environment, before the use of enzyme activities as indicators of the toxicity for soils of any given IL, it is necessary to test if classical methods to determine the soil enzymatic activities are adequate for their use in soils spiked with that given IL.

In this study we investigated the suitability of dehydrogenase method to determine the activity

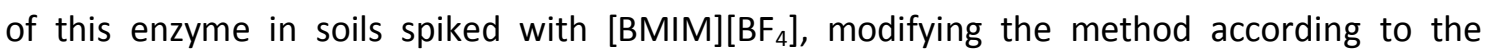
problems identified. 


\section{Material and Methods}

\section{Soils}

For this study two forest soils developed under oakwood vegetation were selected. The surface horizon $(0-10 \mathrm{~cm})$ was collected after removing the litter layer, and the soils were immediately transported to the laboratory in isothermal bags and maintained at $4{ }^{\circ} \mathrm{C}$ until the beginning of the experiments and dehydrogenase activity determinations. An aliquot of each sample was air-dried $\left(20^{\circ} \mathrm{C}\right)$ and used for $\mathrm{pH}$ and particle size analysis; part of this air-dried soil was finely ground and used for total $\mathrm{C}$ and $\mathrm{N}$ contents determination. The soils were acid $(\mathrm{pH}$ in $\mathrm{KCl} 3.83$ and 4.17), with a sandy-loam texture and with very different organic matter contents. Thus, the total $\mathrm{C}$ content was 2.26 and $11.05 \%$, while the total $\mathrm{N}$ content was 0.19 and $0.84 \%$ for soils 1 and 2 , respectively (Table 1 ).

Table 1. (Physico)-chemical properties of the soils used in the study.

\begin{tabular}{ccccccccc}
\hline & $\mathrm{pH} \mathrm{H}_{2} \mathrm{O}$ & $\mathrm{pH} \mathrm{KCl}$ & Total C (\%) & Total N (\%) & $\mathrm{C} / \mathrm{N}$ & Sand (\%) & Silt (\%) & Clay (\%) \\
\hline SOIL 1 & $5.31 \pm 0.00$ & $4.17 \pm 0.01$ & $2.26 \pm 0.04$ & $0.19 \pm 0.00$ & 12 & 78 & 16 & 6 \\
SOIL 2 & $4.38 \pm 0.01$ & $3.83 \pm 0.01$ & $11.05 \pm 0.11$ & $0.84 \pm 0.02$ & 13 & 62 & 25 & 13 \\
\hline
\end{tabular}

\subsection{Chemicals}

The 1-butyl-3-methylimidazolium tetrafluoroborate ([BMIM] $\left.\left[\mathrm{BF}_{4}\right]\right)$ was purchased from IOLITEC

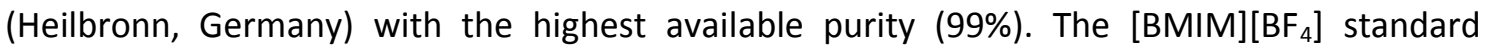
solutions were prepared by dilution of the stock solution in distilled water.

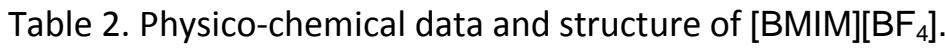
Compound
E.F.
CAS
M.W.
Structure

$\left[\mathrm{BMIM}^{2}\left[\mathrm{BF}_{4}\right] \quad \mathrm{C}_{8} \mathrm{H}_{15} \mathrm{BF}_{4} \mathrm{~N}_{2} \quad 174501-65-6 \quad 226\right.$

Table 2 shows the empirical formula (E.F.), chemical abstract service (CAS) registry number, molecular weight (M.W.) and chemical structure of [BMIM][BF $]$.

\subsection{Experiment set-up}

Different solutions of $[\mathrm{BMIM}]\left[\mathrm{BF}_{4}\right]$ were prepared by dilution of this compound in distilled water, to reach final concentrations of $0.01,0.1,1,10,25,50,75$ and $100 \%$. Thereafter, the 
soils were spiked with $0.1 \mathrm{ml}$ of each of the above solutions per gram of soil and maintained at $20{ }^{\circ} \mathrm{C}$ for 24 hours. A soil sample without addition of [BMIM] $\left[\mathrm{BF}_{4}\right]$, but to which identical

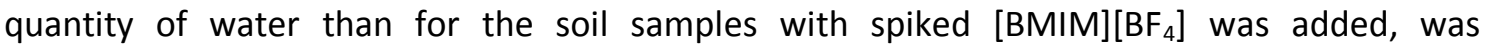
maintained as a control ( $0 \%$ dose). The final concentrations of $[\mathrm{BMIM}]^{-}\left[\mathrm{BF}_{4}\right]$ solutions used to spike the soils varied depending on the aim of the experiments.

The soil-[BMIM] $\left[\mathrm{BF}_{4}\right]$ mixtures were analysed for: $\mathrm{pH}$ in water and in $1 \mathrm{M} \mathrm{KCl}, \mathrm{pH}$ of the soil[BMIM] $\left[\mathrm{BF}_{4}\right]$ mixture with TRIS-HCl buffer at different $\mathrm{pHs}$, and dehydrogenase activity at the selected buffer pHs.

\subsection{Analytical methods}

\subsubsection{Dehydrogenase activity}

Dehydrogenase activity was determined with iodonitrotetrazolium violet (INT) as substrate, incubating in the dark at $40{ }^{\circ} \mathrm{C}$ with $1 \mathrm{M}$ TRIS- $\mathrm{HCl}$ buffer $\mathrm{pH} 7.5$ for 1 hour. The iodonitrotetrazolium formazan (INTF) produced was extracted with a 1:1 (v:v) mixture of ethanol and dimethylformamide (ethanol:DMF) and measured spectrophotometrically at 490 $\mathrm{nm}$ (Camiña et al., 1998). The activity was quantified by reference to a calibration curve constructed using INTF standards incubated with soil under the same conditions described above, and is expressed in $\mu$ mol INTF $g^{-1} h^{-1}$.

\subsection{2. (Physico)chemical properties of the soils}

The soils were analysed for $\mathrm{pH}$ in water and in $1 \mathrm{M} \mathrm{KCl}$, total carbon and nitrogen content and particle size analysis following the methods described in Guitián-Ojea and Carballas (1976). The $\mathrm{pHs}$ of the spiked soil samples were measured by the same method used for non-spiked soils.

The $\mathrm{pH}$ of all spiked samples with TRIS- $\mathrm{HCl}$ at different $\mathrm{pHs}$ were measured before and after incubation $1 \mathrm{~h}$ of incubation in the dark at $40{ }^{\circ} \mathrm{C}$.

\section{Results and Discussion}

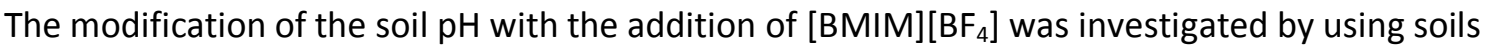
1 and 2 (with a very different organic matter content) and by the addition of a wide range of concentrations of $\left[\mathrm{BMIM}^{\mathrm{M}}\left[\mathrm{BF}_{4}\right]\right.$, from 0.01 to $100 \%$. The results show that the dose of $100 \%$ [BMIM] $\left[\mathrm{BF}_{4}\right]$ has a clear acidifying effect on both soils, while for lower doses (up to $10 \%$ ) the $\mathrm{pH}$ remained unchanged (Table 3). The decrease of $\mathrm{pH}$ at the $100 \%$ dose was very intense, reaching values of $\mathrm{pH}$ in $\mathrm{KCl}$ as low as 2.58 and 1.80 for soil 1 and 2, respectively, i.e. the 
decrease of $\mathrm{pH}$ was slightly more intense in the soil with the lowest $\mathrm{pH}$ and highest organic matter content. At lower doses there was not a decrease but is some instances even a slight increase of soil pH was observed. The acidifying effect would be explained by the hydrolysis of $[\mathrm{BMIM}]\left[\mathrm{BF}_{4}\right]$ and the consequent release of hydrogen fluoride, a process that has been previously described for ILs containing fluoric groups (Pérez de los Ríos y Hernández, 2014; Yu et al., 2016). The strong decrease of $\mathrm{pH}$ at the $100 \%$ dose suggest that the soil's acidifying effect of $[\mathrm{BMIM}]\left[\mathrm{BF}_{4}\right]$ would start at intermediate doses between 10 and $100 \%$, and therefore for the following experiments the lowest doses (0.01 and $0.1 \%$ ) were substituted by higher doses (25, 50 and $75 \%)$.

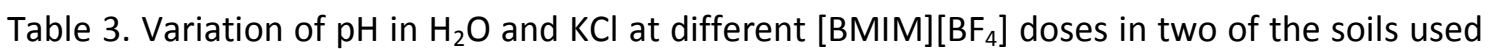
in the study.

\begin{tabular}{ccccc}
\hline \multirow{2}{*}{$\begin{array}{c}\text { [BMIM] } \\
\text { dose }\end{array}$} & $\left.\mathrm{BF}_{4}\right]$ & \multicolumn{2}{c}{ SOIL 1 } & \multicolumn{2}{c}{ SOIL 2 } \\
\cline { 2 - 5 } & $\mathrm{pH} \mathrm{H}_{\mathbf{2}} \mathrm{O}$ & $\mathrm{pH} \mathrm{KCl}$ & $\mathrm{pH} \mathrm{H}_{\mathbf{2}} \mathrm{O}$ & $\mathrm{pH} \mathrm{KCl}$ \\
\hline $\mathbf{0} \%$ & 4.80 & 3.66 & 4.22 & 3.42 \\
$\mathbf{0 . 0 1 \%}$ & 4.83 & 3.65 & 4.16 & 3.47 \\
$\mathbf{0 . 1} \%$ & 4.88 & 3.54 & 4.18 & 3.44 \\
$\mathbf{1} \%$ & 5.34 & 3.71 & 4.48 & 3.30 \\
$\mathbf{1 0 \%}$ & 5.30 & 3.93 & 4.60 & 3.37 \\
$\mathbf{1 0 0 \%}$ & 3.97 & 2.58 & 3.01 & 1.80 \\
\hline
\end{tabular}

The assay of dehydrogenase activity is carried out under buffered conditions (1 M TRIS-HCl buffer, $\mathrm{pH}$ 7.5) to keep the reaction mixture during the assay at optimum $\mathrm{pH}$ (between $\mathrm{pH} 7$ and 7.5). However, when this buffer was mixed with the soils, the $\mathrm{pH}$ was much lower than this $\mathrm{pH}$ (Table 4), being the lower the $\mathrm{pH}$ the highest the dose of $[\mathrm{BMIM}]\left[\mathrm{BF}_{4}\right]$ added to the soil.

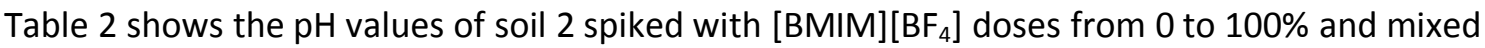
with $1 \mathrm{M}$ TRIS- $\mathrm{HCl}$ buffer $\mathrm{pH} 7.5$, both before and after the incubation $\left(1 \mathrm{~h}\right.$ at $\left.40^{\circ} \mathrm{C}\right)$.

Thus, buffer solutions of different pHs $(7.50,7.70,8.00,8.30$ and 8.50$)$ were used to test if it was possible to rise and maintain the $\mathrm{pH}$ during the incubation period at the optimum $\mathrm{pH}$ for dehydrogenase activity determination. The $\mathrm{pH}$ values determined in soil 2 are shown in table 4. The results indicate that, depending on the dose of $[\mathrm{BMIM}]\left[\mathrm{BF}_{4}\right]$, it was necessary to use different buffer solutions with $\mathrm{pHs}$ between $\mathrm{pH} 7.70$ and 8.50 . For doses above $25 \%$ it was necessary to use TRIS-HCl buffer of $\mathrm{pH} 8.5$, the maximum $\mathrm{pH}$ at which $1 \mathrm{~m}$ TRIS-HCl buffer has an acceptable buffering capacity. 
Table 4. Values of $\mathrm{pH}$ of soil 2 with different $1 \mathrm{M}$ TRIS-HCl buffer solutions ( $\mathrm{pH} 7.50 ; 7.70 ; 8.00$; 8.30 and 8.50) before (N.I) and after (I) incubation. In grey, $\mathrm{pH}$ at the buffer selected for each of the concentrations of spiked [BMIM] $\left[\mathrm{BF}_{4}\right]$. nd =no determined.

\begin{tabular}{|c|c|c|c|c|c|c|c|c|c|c|}
\hline \multirow{2}{*}{$\begin{array}{c}\text { [BMIM] }\left[\mathrm{BF}_{4}\right] \\
\text { dose }\end{array}$} & \multicolumn{2}{|c|}{$\begin{array}{c}\text { Buffer } \mathrm{pH} \\
7.50\end{array}$} & \multicolumn{2}{|c|}{$\begin{array}{c}\text { Buffer pH } \\
7.70\end{array}$} & \multicolumn{2}{|c|}{$\begin{array}{c}\text { Buffer pH } \\
8.00\end{array}$} & \multicolumn{2}{|c|}{$\begin{array}{c}\text { Buffer pH } \\
8.30\end{array}$} & \multicolumn{2}{|c|}{$\begin{array}{c}\text { Buffer } \mathrm{pH} \\
8.50\end{array}$} \\
\hline & N.I & I & N.I & I & N.I & I & N.I & I & N.I & I \\
\hline $0 \%$ & 7.25 & 6.97 & 7.45 & 7.23 & 7.66 & 7.45 & nd & nd & nd & nd \\
\hline $1 \%$ & 7.24 & 6.9 & 7.37 & 7.13 & 7.59 & 7.37 & nd & nd & nd & nd \\
\hline $10 \%$ & 6.85 & 6.49 & 7.11 & 6.82 & 7.43 & 7.12 & 7.45 & 7.19 & nd & nd \\
\hline $25 \%$ & 6.46 & 6.14 & 6.78 & 6.53 & 6.87 & 6.63 & 7.10 & 6.80 & 7.72 & 7.51 \\
\hline $50 \%$ & 6.14 & 5.84 & 6.58 & 6.28 & 6.86 & 6.61 & nd & nd & 7.55 & 7.25 \\
\hline $75 \%$ & 5.85 & 5.53 & 6.36 & 6.07 & 6.65 & 6.41 & nd & nd & 7.50 & 7.20 \\
\hline $100 \%$ & 5.80 & 5.58 & 6.28 & 5.96 & 6.56 & 6.30 & nd & nd & 7.52 & 7.21 \\
\hline
\end{tabular}

Once solved the problem of the $\mathrm{pH}$, the soils were incubated with different concentrations of INTF $\left(0,40,100,200,300\right.$ and $\left.400 \mu \mathrm{g} \mathrm{ml}^{-1}\right)$, to test if the presence of [BMIM][BF 4 could interfere in the measurement of the INTF absorbance. The extraction of the soil-buffer-INTF reaction mixture with etanol:DMF rendered very dark filtrates due to the co-extraction of organic matter, providing erratic values of absorbance, and even in some cases the extracts being too dark to be measured by colorimetry.

Thus, the next step was to test if the addition of $\mathrm{CaCl}_{2}$ to complex organic matter would be a solution to overcome this problem. This is the method used to avoid the brown coloration in the extracts in assays of diverse enzymatic activities involving the measurement of the absorbance of $p$-nitrophenol (Tabatabai, 1982). Different concentrations of $\mathrm{CaCl}_{2}(0.2,0.5,1.0$, 1.5 and $2 \mathrm{M}$ ) and different volumes of these solutions were tested, adding the $\mathrm{CaCl}_{2}$ to the reaction mixture before the addition of the etanol:DMF and the filtration. The results showed that, due to different causes, most of the concentrations and/or volumes added were ineffective to avoid the dark coloration without lowering the absorbance of the INTF standards (Fig. $1 \mathrm{~A}$ ) or even to loss the linearity. Finally, we found that an addition of $0.2 \mathrm{ml}$ of a $5 \mathrm{M}$ $\mathrm{CaCl}_{2}$ solution was effective, giving the same absorbance values the standard line constructed without soil and with the soil spiked with 100\% [BMIM][BF $]$ (Fig. 1 B). 

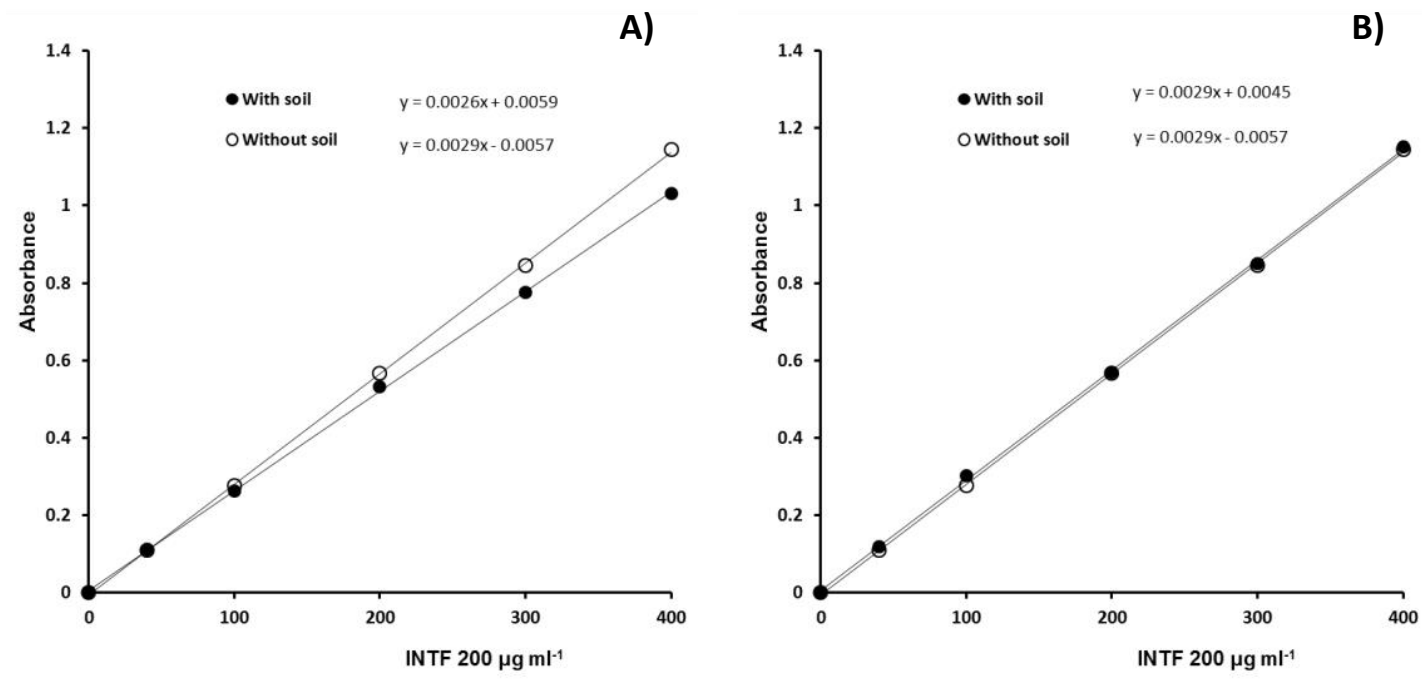

Figure 1. Absorbance values of the standard solutions with and without with soil (soil spiked with $100 \%\left[\mathrm{BMIM}_{[}\left[\mathrm{BF}_{4}\right]\right.$ ) after the addition of A) $1 \mathrm{ml}$ of $1 \mathrm{M} \mathrm{CaCl}_{2}$, and B) $0.2 \mathrm{ml}$ of $\mathrm{CaCl}_{2} 5 \mathrm{M}$.

Thereafter, the dehydrogenase activity of the two soils spiked with $0,1,10,25,50,75$ and $100 \%[\mathrm{BMIM}]\left[\mathrm{BF}_{4}\right]$ was measured. On each case, the $\mathrm{pH}$ of TRIS-HCl buffer was selected after the addition to the soils of solutions at different $\mathrm{pHs}$ and measuring the $\mathrm{pH}$ before and after and incubation of $1 \mathrm{~h}$ at $40^{\circ} \mathrm{C}$ in the dark. After the incubation, $0.2 \mathrm{ml}$ of $5 \mathrm{M} \mathrm{CaCl}_{2}$ were added

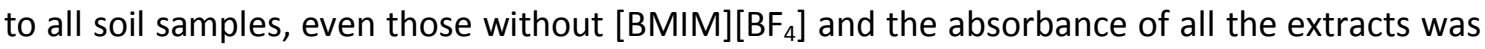
measured at $490 \mathrm{~nm}$.

The presence of $[\mathrm{BMIM}]\left[\mathrm{BF}_{4}\right]$ caused a reduction of dehydrogenase activity for doses above $1 \%$, but the extent of the decrease varied with the soil and with the dose (Fig. 2). The dose of the $1 \%$ did not affect the dehydrogenase activity (soil 1 ) or even caused a slight increase of the activity (soil 2). In general, the decrease of the activity was related with the dose of [BMIM] $\left[\mathrm{BF}_{4}\right]$, being this relation very clear for soil 1 while for soil 2 there was not a clear relation between dose and reduction of the activity, since the activity in the soil spiked with the doses between 10 and 100\% was nearly the same (Fig. 2).

\section{Conclusions}

The addition of $[\mathrm{BMIM}]\left[\mathrm{BF}_{4}\right]$ caused a strong acidification of the soils. To solve this problem, it is necessary to test TRIS-HCl buffer of different $\mathrm{pHs}$ to select that providing the optimum $\mathrm{pH}$ to determine dehydrogenase activity for each soil and dose.

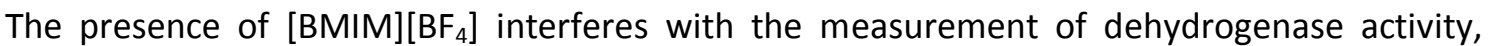
since causes the co-extraction of organic matter rendering very dark coloured extracts. This problem can be easily solved adding $0.2 \mathrm{ml}$ of a $5 \mathrm{M} \mathrm{CaCl}_{2}$ solution to the reaction mixture before the extraction and filtration of the INTF formed. 
The dehydrogenase activity is affected by the presence of $[\mathrm{BMIM}]\left[\mathrm{BF}_{4}\right]$, but the extent of the effect depends on the soil and the dose.
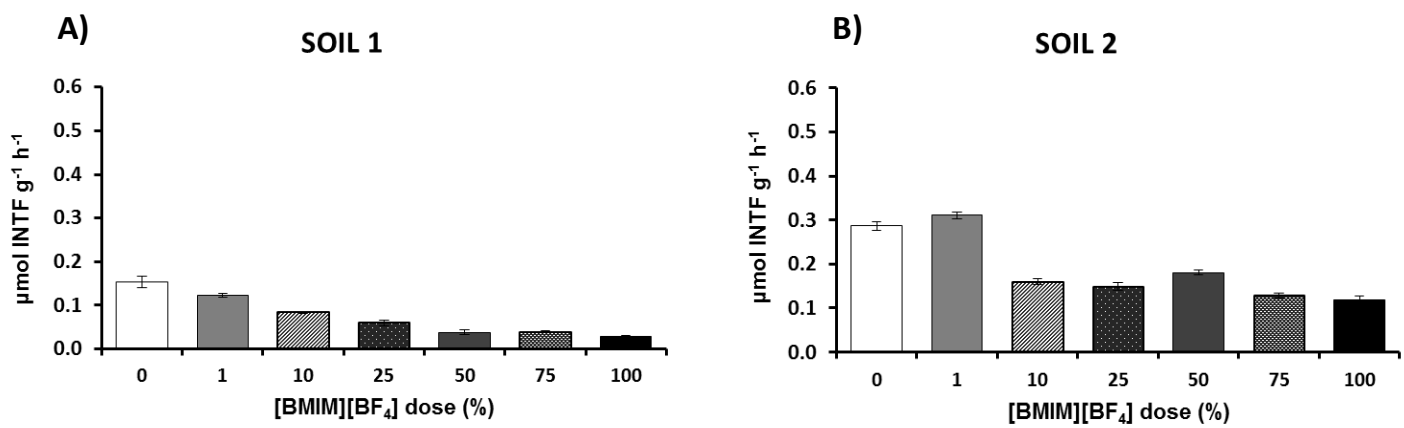

Figure 2. Dehydrogenase activity in the two investigated soils spiked with different doses of [BMIM] $\left[\mathrm{BF}_{4}\right]$.

Acknowledgments. This research was financed by the Spanish Ministerio de Economía y Competitividad (Project No. CGL2015-66857-C2-1-R). The authors thank Ana I. Iglesias-Tojo for assistance in carrying out the analyses.

\section{References}

Camiña F., Trasar-Cepeda C., Gil-Sotres F., Leirós C., 1998. Measurement of dehydrogenase activity in acid soils rich in organic matter. Soil Biology \& Biochemistry 30, 1005-1011.

Cihacek L.J., Anderson W.L., Barak P.W. 1996. Methods for Assessing Soil Quality. In: Methods for Assessing Soil Quality (Doran J.W., Jones A.J., eds.). Soil Science Society of America American Society of Agronomy, Madison, Wisconsin, pp. 9-24.

Dick R.P., 1997. Soil enzyme activities as integrative indicators. In: Biological Indicators of Soil Health (Pankhurst, C.E., Doube, B.M., Gupta, V.V.S.R., eds.). CAB International, Wallingford, UK, pp. 121-156.

Doran J.W., Parkin T.B., 1994. Defining and Assessing Soil Quality. In: Defining Soil Quality for a Sustainable Environment (Doran J.W., Coleman D.C., Bezdicek D.F., Stewart B.A., eds.). Soil Science Society of America - American Society of Agronomy, Madison, Wisconsin, pp. 321.

García C., Hernández T., 1997. Biological and biochemical indicators in derelict soils subject to erosion. Soil Biology \& Biochemistry 29, 171-177.

Guitián-Ojea F., Carballas T., 1976. Técnicas de Análisis de Suelos. Pico Sacro Editorial, Santiago de Compostela, España.

Pérez de los Ríos A., Hernández F.J., 2014. Ionic Liquids in Separation Technology. Elsevier, Amsterdam, The Netherlands. 
Salgado J., Villanueva M., Parajó J.J., Fernández J., 2013. Long-term thermal stability of five imidazolium ionic liquids. The Journal of Chemical Thermodynamics 65, 184-190.

Skujins J., 1973. Dehydrogenase: as an indicator of biological activity in arid soils. Bulletin of Ecological Research Communications, Stockholm 17, 235-241.

Skujins J., 1976. Extracellular enzymes in soil. Critical Reviews in Microbiology 4, 383-421.

Tabatabai M.A., 1982. Soil Enzymes. In: Methods of Soil Analysis, Part 2. Chemical and Microbiological Properties, 2nd Edition. (Page A.L., Miller R.H., Keeney D.R., eds.). American Society of Agronomy-Soil Science Society of America, Madison, Wisconsin, pp. 903-947.

Trasar-Cepeda C., Leirós M.C., Seoane S., Gil-Sotres F., 2000. Limitations of soil enzymes as indicators of soil pollution. Soil Biology \& Biochemistry 32, 1867-1873.

Trevors J.T., 1984. Dehydrogenase activity in soil: a comparison between the INT and TTC assay. Soil Biology \& Biochemistry 16, 673-674.

Verdía P., Vilas M., Mahrova M., Santamarina F., Tojo E., 2012. Design and synthesis of new ionic liquids for specific applications. International Workshop on Ionic Liquids. Seed for New Engineering Applications. Lisboa, Portugal.

Visser S., Parkinson D., 1992. Soil biological criteria as indicators of soil quality: soil microorganisms. American Journal of Alternative Agriculture 7, 33-37.

Yu J., Zhang S., Dai Y., Lu X., Lei Q.,Fang W., 2016.Antimicrobial activity and cytotoxicity of piperazinium- and guanidinium-based ionic liquids. Journal of Hazardous Materials 307, 73-81. 